\title{
Determinants of Capital Structure on Trading and Manufacturing Enterprises: A Case of Nepal
}

\author{
Shanker Dhodary, M.Phil. \\ Lecturer \\ Nepal Commerce Campus, Faculty of Management, T.U.
}

\begin{abstract}
This study mainly aimed at examining the determinants of capital structure in Nepalese trading and manufacturing firms. The study has covered eleven major non-financial enterprises of trading and manufacturing firm's specific variables. Firm's size, growth opportunity, asset tangibility, profitability, firm's age, liquidity and interest coverage ratio have selected as variables to examine their effect on corporate capital structure. The study used both descriptive and causal comparative research design to examine the determinants of capital structure. Data required for undertaking the study were collected from secondary sources. For each enterprise, financial data for 10 fiscal years covering the period of F/Y 2005/2006 to F/Y 2015/2016.The study concluded that asset tangibility, profitability, liquidity and interest coverage ratio are the major determinants of corporate capital structure in Nepalese trading and manufacturing firms.
\end{abstract}

Keywords: Leverage, Firm size, Tangibility, Firm's age, Profitability, Liquidity

\section{Introduction}

The capital structure is the mix of debt, preferred stock, and common equity. At the capital structure where the weighted average cost of capital is minimized, the total value of the firm's securities is maximized. As a result, the minimum cost capital structure is called the optimal capital structure. Capital structure has remained as a controversial topic in financial management arena for decades. As a result, the minimum-cost capital structure is called the optimal capital structure.

The amount of debt contained in a firm's debt contained in a firm's optimal capital structure is often referred to as the firm's debt capacity. The optimal capital structure and, accordingly, the debt capacity of the firm are determined by factors including the business risk of the firm, the tax structure, the extent of the optimal financial distress and agency costs, and the role played by capital structure policy in proving signals to the capital markets regarding the firm's performance

Capital structure is also known as financial plan of the firms. Each firm undertakes some kind of capital structure planning. Thus, capital structure is part of the financial structure, representing the permanent sources of the firms financing.

Thus, a firm's capital structure is only a part of financial structure. One of the issues in firm's corporate financing decisions is the decisions is the decisions about what portion of debt should be used to finance the assets. The capital structure design seeks the answers of quarries such as division of total fund sources into short-term and long-term components. The major influence on the maturity structure of financing plan is the nature of the assets owned by the firm. If the company has more of fixed assets, it should finance them with permanent types of financial capital (Hunsaker, 1999). The central focus on ratio of debt, preferred stock and equity to total assets ratio. If the proper mix of the above capital can be found, the firm's common stock price will be maximized. However, the proper mix of permanent financing. This is the basic issue in capital 
structure management. An enduring controversy within the arena of financial theory concerns the effect of financial advantage on the overall cost of capital to the firms.

If the firm's cost of capital can affect by its capital structure, then capital structure is clearly an important subset of business financial management. Attempts to answer the above question have comprised a significant portion of capital structure theory for over three decades or so.

Many studies have conducted to answer, however there are no unanimous findings. Some studies indicated that by changing the capital structure, the firm could affect cost of capital or market price per share while other studies did not indicate the same. However, most financial executives and financial academics subscribe to the concept of an optimal capital structure. The optimal capital structure minimizes the firm's composite cost of capital. Searching for a proper range of financial leverage use, Ross (1977).

These studies directed towards examining the determinants of corporate capital structure and applicability of the variables derived from developed economy. Studies have shown mixed effects in relation to the determinants of corporate capital structure of Nepalese enterprises. Study's findings are different in accordance with their methodological approach. In view of this context and reality, the present study has been undertaken. The major objective of this study is to examine the determinants of capital structure of Nepalese trading and manufacturing firms.

The study seeks to test the following hypotheses.

H1: There is positive relationship between total leverage and size of the firm.

H2: There is positive relationship between total leverage and growth of the firm.

H3: There is positive relationship between total leverage and asset Tangibility

H4: There is negative relationship between total leverage and profitability

H5: There is positive relationship between total leverage and Firm's age

H6: There is negative relationship between total leverage and liquidity of the firm.

H7: There is positive relationship between total leverage and interest coverage.

\section{Literature Review}

Modigliani and Miller (1958) indicated that the relationship between leverage and the cost of capital is explained by the net operating income approach. They supported the net operating income approach and suggested that there is no one optimal capital structure. They made a formidable attack on traditional position. MM offered behavioral justification for the independence of the total value and cost of capital of the firm.

Myers and Majluf(1984) argued that if managers have better information about the future investment opportunities of the firm than the potential investors do, they might find it difficult to get external finance. This is because outsiders ask for a premium in order to compensate for the possibly of finding a bad firm. If the firm tries to finances, its new projects by issuing equity, then the under-pricing may be so severe that a good firm may find it profitable to reject some of its projects even with positive net present value (NPV). Thus the firm will always try to choose a security, which minimizes this problem known as Lemon problem.

Sharma (1995) observed the pattern of capital structure of Indian companies belonging to manufacturing industries. The study concluded that profitability is positively associated with leverage. Asset structure, costs of debt and working capital were significantly negatively associate to leverage except in few sample groups.

Rajan and Zingales (1995) observed the difference in leverage and its determinants in G7 countries. It was a investigation of capital structure determinants directed towards examining whether or not factors identified in United States seem similarly related in other countries as well. The study found aggregate leverage and determinants are both roughly identical across these countries. 
Shrestha (1985) analyzed capital structure of selected Nepalese public enterprises. The study mainly focused on analyzing the trend of capital structure in public enterprises Based on the analysis; the study concluded that there are low capital gearing and even unbalance pattern of capital structure among the selected public enterprises of Nepal.

Poudel (1994) found the determinants of major affecting variables on capital structure in Nepalese enterprises. The study concluded that size, profitability, growth, assets structure and cash flow variability have the influence on the capital structure. Further, size and growth were positively related to leverage and risk, profitability and assets structure were negatively related to leverage for both listed companies and PEs.

Baral (2004) attempted to examine the determinants of capital structure-size, business risk, growth rate, earning rate, dividend payout, debt service capacity and degree of operating leverage-of the companies listed to Nepal Stock Exchange Ltd. as of July 16, 2003. Eight variables multiple regression model has been used to assess the influence of defined explanatory variables on capital structure. The study showed that size, growth rate and earning rate are statistically significant determinants of capital structure of the listed companies.

\section{Conceptual framework}

This section directed towards reviewing the theoretical development of capital structure and major empirical researches carried out in the field of study area. Based on the review of available literature, following theoretical framework has developed as shown in figure.

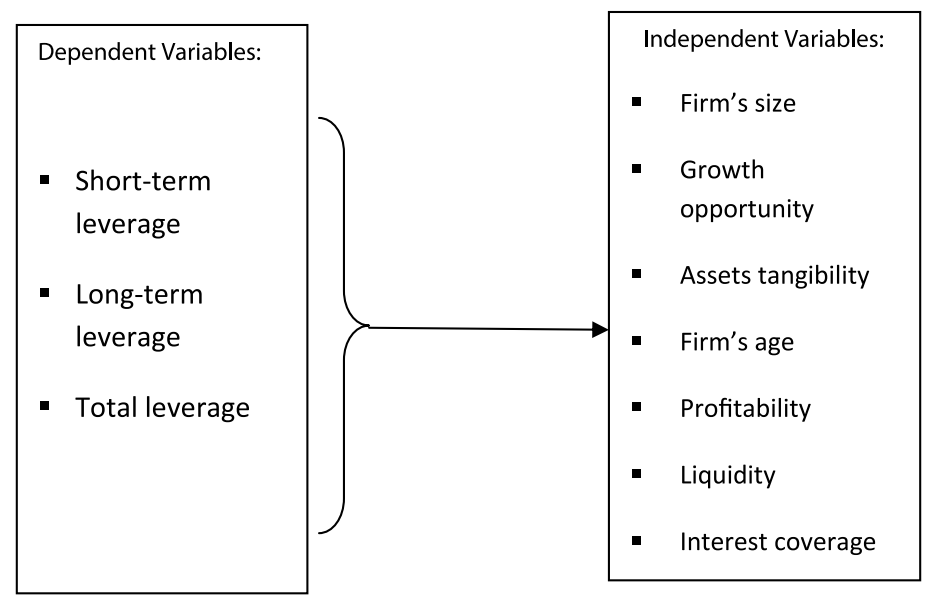

Fig. Theoretical framework

\section{Research design}

The causal comparative research design has been used to examine the association among selected variables, and cause and effect relationship among leverage measures and other independent variables. Correlation among the selected variables has been examined by using the Pearson's correlation coefficients. Cause and effect relationship between dependent and independent variables has been examined by estimating Ordinary Least Square (OLS) regression models, which is directed to uncover the determinants of corporate capital structure of the industries.

\section{Nature and sources of data}

Data required for undertaking the study has been collected from secondary sources. Mixed data collection techniques have been used to collect the necessary data, and information required for undertaking the study. The secondary data have been collected from the annual reports of the concerned firms by undertaking organizational visits. For each firms financial data for 10 fiscal years covering the period of $\mathrm{F} / \mathrm{Y}$ 2005/2006 to F/Y 2015/2016 has been collected. 


\section{Population and sample}

This study is directed towards examining the determinants in Nepalese trading and manufacturing sector. Therefore, all listed trading and manufacturing firms in NEPSE constitutes the population of the study. These firms represent trading and manufacturing sectors as classified by the NEPSE. From this population, all together 11 enterprises representing the above stated sector has been selected as sample enterprises for in- depth study.

\section{Selection of variables}

The study uses three measures of corporate capital structure: (1) short-term debt to total asst, (ii) longterm debt to total assets, and (iii) total debt to total assets as dependent variables. The firms' specific variables that cover firm's size (SIZE), sales growth (GROWTH), Asset Tangibility (TANG), profitability (PROFY), and age (AGE), liquidity (LIQUY) have been used as explanatory variables. The three measures of corporate capital structure used in this study have been presented here under.

Short-term Financial Leverage $(\mathrm{STL})=$ Short-term Debt $/$ Total Assets $=$ STD $/$ TA

Long - term Financial Leverage $(\mathrm{LTL})=$ Long-term Debt $/$ Total Assets $=$ LTD $/$ TA

Total Financial Leverage $($ TFL $)=$ Total Debt $/$ Total Assets $=$ TD $/$ TA

\section{Empirical model}

This study uses the following model to determine the impact of firm specific variables on corporate capital structure of Nepalese trading and manufacturing firms. In all cases, three measures of corporate financial leverage viz. short-term, long-term, and total leverage have been used.

$$
\begin{gathered}
\text { LEVERAGE }=\alpha_{i}+\beta_{1}(\text { SIZE })+\beta_{2}(\text { GROWTH })+\beta_{3}(\text { TANGIBILITY })+\beta_{4}(\text { PROFITABILITY })+\beta_{5} \\
(\text { AGE })++\beta_{6}(\text { LIQUIDITY })+B 7(\text { INT.COVG. })+\varepsilon_{i}
\end{gathered}
$$

\section{Data processing and analysis}

Information collected from different source have been compiled and coded as per requirement. Necessary tables have been prepared for the analysis. Analysis has been done using quantitative assessment framework to draw the meaningful conclusions.

\section{Analytical tools used in the study}

The study has used mixed statistical tools for the purpose of analysis of data. Primarily, the following descriptive and inferential statistics have been used for analyzing the data.Several descriptive statistical tools such as average, minimum, maximum and standard deviation have been used to describe the data set and the state of an art of corporate financial leverage among the firms covered under the study. Such tools have been used for analyzing the secondary information.

\section{Determinants of capital structure in trading and manufacturing enterprises}

Descriptive statistics presented in the first part of analysis reveals differences among the enterprises in terms of extent of use of different measures of financial leverage. In line with this kind of difference, attempts have been made to examine the determinants of capital structure of trading and manufacturing sector.

Eleven enterprises viz. BishalBazzar Company Limited (BBCL), Salt Trading Limited (STL),Bottlers Nepal Limited,Balaju(BNLB), Bottlers Nepal Tarai Limited (BNTL), Himalyan Distillery Company Limited (HDL), Nepal Bitumen and Barrel Udyog Limited(NBL),Nepal Fleur Himalayan Limited(NFHL), Nepal KhadyaUdyog Limited (NKUL),Nepal Lube Oil Limited(NLOL),Shri Ram Sugar Mills Limited (SSML), Uniliver Nepal Limited (UNL) represent from trading and manufacturing sector. 
Vol. 4, No. 1

\section{Correlation coefficient between the variables}

Table depicts the correlation analysis of the major variables under study. The three different measures of financial leverage of trading and manufacturing sector enterprises have been correlated with seven firms' specific variables viz. firm's size, growth opportunity, asset tangibility, profitability, age, liquidity and interest coverage ratio.

Table 1 Correlation coefficients among the variables

This table presents Pearson correlation coefficient among different variables used in the study. The data are extracted from the annual reports of sample firms.

\begin{tabular}{|l|l|l|l|l|l|l|l|l|l|l|}
\hline \multicolumn{1}{|c|}{ Variables } & \multicolumn{1}{|c|}{ STL } & \multicolumn{1}{c|}{ LTL } & \multicolumn{1}{c|}{ TL } & Size & Growth & $\begin{array}{c}\text { Tangi } \\
\text { bility }\end{array}$ & $\begin{array}{c}\text { Profita } \\
\text { bility }\end{array}$ & Age & Liquidity & $\begin{array}{c}\text { Int. } \\
\text { coverage }\end{array}$ \\
\hline STL & 1 & & & & & & & & & \\
\hline LTL & $-0.280^{*}$ & 1 & & & & & & & & \\
\hline TL & $0.315^{* *}$ & $0.416^{*}$ & 1 & & & & & & & \\
\hline Size & 0.394 & 0.295 & 0.423 & 1 & & & & & & \\
\hline Growth & $0.402^{* * *}$ & 0.438 & 0.514 & 0.138 & 1 & & & & & \\
\hline Tangibility & $-0.214^{* *}$ & $0.327^{* *}$ & $0.431^{* *}$ & $0.167^{*}$ & $0.163^{* *}$ & 1 & & & & \\
\hline Profitability & -0.213 & $-0.419^{*}$ & $-0.296^{* *}$ & 0.164 & 0.172 & $0.186^{* *}$ & 1 & & & \\
\hline Age & 0.294 & 0.373 & 0.275 & $0.253^{* *}$ & 0.094 & $0.247^{* *}$ & 0.143 & 1 & & \\
\hline Liquidity & $-.306^{* *}$ & $-0.458^{* *}$ & $-0.452^{* *}$ & 0.091 & $-0.159^{* *}$ & $-0.329^{* *}$ & $-0.192^{*}$ & 0.227 & 1 & \\
\hline Int. coverage & $0.295^{* *}$ & $0.456^{* *}$ & $0.392^{* *}$ & 0.372 & $0.247^{* * *}$ & $0.316^{* * *}$ & $0.353^{*}$ & 0.158 & $0.310^{* * *}$ & 1 \\
\hline
\end{tabular}

*. Correlation is significant at 0.01 level (2 tailed). **.Correlation is significant at 0.05 level (2 tailed). ***.Correlation is significant at 0.1 level (2 tailed).

As exhibited in Table 1, firm's size is positively correlated with all measures of leverage. The coefficients are 0.394 for short-term leverage, 0.295 for long- term leverage and 0.423 for total leverage respectively. All these coefficients are as per the priori expected hypothesis However, they are not statistically significant. It indicates that size has no association with capital structure in Nepalese non-financial firms.

Although growth opportunity is positively correlated with all measures of leverage, the correlation is statistically significant only with short-term leverage (0.402) at 10 percent level of significance. It indicates that that growth opportunity has no significant effect on the use of long-term and total debt in Nepalese trading and manufacturing enterprises.

The variable tangibility is negatively and significantly correlated with short-term financial leverage at 1 percent level $(-0.214)$ but positively correlated with long-term and total leverage indicating that firms having higher tangible assets use less short-term debt and use the assets as collateral to obtain medium or long-term loan from the financial institutions.

The relationship has been found between profitability and all measures of financial leverage. However, coefficient is not statistically significant for short-term leverage; indicating that profitable Nepalese nonfinancial firms tend to use lower long- term and total debt. But use of short-term debt is not affected by their profitability. Although the variable age is positively correlated with all measures of leverage, the relationship is not statistically significant. This result indicates that firm's age is not expected as a major determinant of corporate financial leverage in Nepalese trading and manufacturing enterprises. The insignificant relationship between age and financial leverage is not in line with the priori hypothesis.

Association between corporate liquidity and all measures of financial leverage is negative and statistically significant viz. $-0.306,-0.458$ and -0.452 . As exhibited in the table, all these coefficients are statistically significant. This result indicates that firms having higher liquidity tend to use lower debt. This is consistent with the priori hypothesis. 
Finally, correlation coefficients between interest coverage ratio and all masseurs of financial leverage are positive respectively 0.295 for short-term leverage, 0.456 for long-term leverage and 0.392 for total leverage. All these coefficients are statistically significant at 5 percent level of significance; indicating that trading and manufacturing enterprises having higher coverage ratio can employ higher debt in their capital structure.

\section{Determinants of total leverage in trading and manufacturing enterprises}

The total leverage in this study has been defined as the ratio of total debt to total assets, which shows the extent of debt financing used to acquire the total assets of the firm. Table presents the results of regression models designed to analyze the impact of seven firms' specific variables on total leverage in Nepalese trading and manufacturing enterprises.

Table 2: Total financial leverage for trading and manufacturing enterprises

\begin{tabular}{|c|c|c|c|c|c|c|c|c|c|c|c|}
\hline Model & Constant & Size & Growth & Tang & Profy & Age & Liqui & Int.covg. & Adjusted R ${ }^{2}$ & $\mathbf{F}$ & Sig. \\
\hline 1 & $\begin{array}{c}-0.073 * * \\
(0.043)\end{array}$ & $\begin{array}{c}0.052 \\
(0.175)\end{array}$ & & & & & & & 0.332 & 73.576 & 0.000 \\
\hline 2 & $\begin{array}{l}-0.673 \\
(0.127)\end{array}$ & & $\begin{array}{c}0.036 \\
(0.136)\end{array}$ & & & & & & 0.321 & 92.723 & 0.001 \\
\hline 3 & $\begin{array}{l}1.417^{*} \\
(0.007)\end{array}$ & & & $\begin{array}{c}0.196^{* *} \\
(0.027)\end{array}$ & & & & & 0.343 & 98.216 & 0.000 \\
\hline 4 & $\begin{array}{c}-.803 \\
(0.167)\end{array}$ & & & & $\begin{array}{l}-0.279^{*} \\
(0.001)\end{array}$ & & & & 0.371 & 84.721 & 0.001 \\
\hline 5 & $\begin{array}{c}0.671 * * \\
(0.027)\end{array}$ & & & & & $\begin{array}{c}0.058 \\
(0.147)\end{array}$ & & & 0.368 & 64.725 & 0.000 \\
\hline 6 & $\begin{array}{c}0.173 \\
(0.168)\end{array}$ & & & & & & $\begin{array}{l}-0.198 * \\
(0.005)\end{array}$ & & 0.429 & 83.613 & 0.000 \\
\hline 7 & $\begin{array}{l}1.357^{*} \\
(0.000)\end{array}$ & & & & & & & $\begin{array}{c}0.303^{* *} \\
(0.049)\end{array}$ & 0.353 & 56.943 & 0.001 \\
\hline 8 & $\begin{array}{c}-0.328^{* *} \\
(0.046)\end{array}$ & $\begin{array}{c}0.046 \\
(0.138)\end{array}$ & $\begin{array}{c}0.032 \\
(0.188)\end{array}$ & $\begin{array}{c}0.178^{* *} \\
(0.021)\end{array}$ & & $\begin{array}{c}0.052 \\
(0.172)\end{array}$ & & $\begin{array}{l}0.284^{*} \\
(0.021)\end{array}$ & 0.315 & 52.623 & 0.000 \\
\hline 9 & $\begin{array}{c}2.637 \\
(0.149)\end{array}$ & & $\begin{array}{c}0.029 \\
(0.172)\end{array}$ & $\begin{array}{c}0.164 * * \\
(0.032)\end{array}$ & $\begin{array}{c}-0.251^{*} \\
(0.000)\end{array}$ & & $\begin{array}{c}-0.167^{*} \\
(0.000)\end{array}$ & & 0.382 & 107.347 & 0.001 \\
\hline 10 & $\begin{array}{c}0.364^{* *} \\
(0.028)\end{array}$ & $\begin{array}{c}0.039 \\
(0.177)\end{array}$ & $\begin{array}{c}0.024 \\
(0.159)\end{array}$ & $\begin{array}{l}0.136^{*} \\
(0.000)\end{array}$ & $\begin{array}{c}-0.228^{* *} \\
(0.043)\end{array}$ & $\begin{array}{c}0.049 \\
(0.176)\end{array}$ & $\begin{array}{l}-0.139 * \\
(0.006)\end{array}$ & $\begin{array}{c}0.237 * * \\
(0.024)\end{array}$ & 0.417 & $89 . .615$ & 0.000 \\
\hline
\end{tabular}

Table 2 exhibits the result of regression models of total leverage for trading and manufacturing enterprises. All models are significant as evidenced by an overall $\mathrm{F}$ statistics. In model 1 , total financial leverage has been regressed with SIZE (proxy of firm's size) and the coefficient has been found positive (0.052) as per priori expected sign. However the regression coefficient is not statistically significant. The size variable has been further included in model- 8 and model- 9 with other independent variable to confirm its effect on total leverage. As exhibited in table all coefficients of regression models are not statistically significant. The result indicates that use of total debt in Nepalese trading and manufacturing enterprises is not affected by their size.

As exhibited in table, the variable GROWTH has positive coefficient as per priori expected sign (0.036).However, the coefficient is not statistically significant. In addition to this, it has been further included in three multivariate models viz. in model-8, model-9 and model-10. The result of multivariate analysis also shows the positive but insignificant effect of growth opportunity on total leverage. This result indicates that the growth opportunity is irrelevant for the use of total debt by Nepalese trading and manufacturing enterprises. 
Vol. 4, No. 1

Coefficients of TANG (proxy of asset tangibility) has been found positive and statistically significant in all models viz. in model-3 (0.196), model-8(0.178), model-9(0.164) and model-10 (0.136).Further all coefficients are statistically significant .It indicates that Nepalese trading and manufacturing enterprises with more tangible assets use more debt in their capital structure.

In relation to the effect of profitability (PROFY) on total leverage, the coefficient is negative $(-0.279)$ as per priori expected sign and statistically significant. Same result is observed in other two multivariate models viz. -0.251 and -0.228 . This result indicates that profitable Nepalese trading and manufacturing enterprises borrow less to finance their assets.

As depicted in table, coefficient of the variable AGE (age of business) has been found positive in all regression models in model respectively in model-5 (0.058), model- $8(0.052)$, and model $-10(0.049)$ as per priori expected sign. However, all these coefficients are not statistically significant. The result indicates that age of the enterprise has no effect on the use of total debt in trading and manufacturing enterprises. This result is consistent with the finding of Bhattarai (2008).

Regarding the impact of liquidity (LIQY) on total leverage of trading and manufacturing enterprises, coefficient has been found negative $(-0.198)$ and statistically significant. This relationship is further examined in two multivariate models. In all models sign of the coefficients have been found negative and statistically significant at $1 \%$ level of significance. The result indicates that Nepalese trading and manufacturing enterprises with high liquidity tend to avoid raising external loan capital.

Finally, an attempt has been made examine the effect of interest coverage on total leverage of trading and manufacturing enterprises. As exhibited in the table, the coefficient has been found positive $(0.303)$ in univariate analysis. The variable is further included in model- 8 and model-10 with other variables to confirm the impact on total leverage. As reported in table, all coefficients are as per priori expectation and are statistically insignificant. This result indicates that the higher the interest coverage, the higher the total debt in the capital structure of Nepalese trading and manufacturing enterprises.

\section{Summary}

This study mainly aimed at examining the determinants of capital structure in Nepalese trading and manufacturing firms. Its specific objectives are: to identify the determining the capital structure of the trading and manufacturing firms. Analysis has been done both at aggregate and industry level to examine the effect of various factors on the capital structure across the industry and organized into various sections. The first section presents the structure and patter of variables and capital structure measures. Summary of descriptive statistics has been presented in second section. Test of differences in capital structure measures has been carried out and also devoted towards examining the determinants of capital structure in all sample enterprises. The study concludes that asset tangibility, profitability, liquidity and interest coverage ratio are the major determinants of corporate capital structure in Nepalese trading and manufacturing firms.

\section{Conclusions}

Based on above findings, the study concludes that asset tangibility, profitability, liquidity and interest coverage ratio are the major determinants of corporate capital structure in Nepalese trading and manufacturing firms. Capital structure of the Nepalese trading and manufacturing enterprises is positively affected by asset tangibility and interest coverage ratio and negatively affected by the corporate profitability and liquidity. Variables size, growth opportunity and age are not determinants of capital structure of trading and manufacturing enterprises of Nepal.

\section{Discussions}

This study was directed to examine the determinants of capital structure in Nepalese trading and manufacturing firms. It has found that asset tangibility, profitability, liquidity and interest coverage ratio with varied effect in accordance with the measures of leverage and industry category. Variables size, 
growth opportunity and age are not the major determinants of capital structure of non-financial enterprises of Nepal.

The study has found positive relationship between asset tangibility and leverage. This result indicates that companies with more tangible assets use more long-term debt. It is analogous with the finding of Corneil et al. (1996) and Casser and Homles (2003). Similarly, the negative relationship between leverage and profitability uncovered by the study is consistent with pecking order theory and findings of Rajan and Zingales. (1995).

\section{References}

Annuar, M. N., \&Shamsher, M. (1993). Capital Structure. Capital Market Review.

Bancel, F. \&Mitto, U.R. (2004).Cross-country determinants of capital structure choice: A survey of European Firms, Financial Management, (33).

BaralK. J. (1996). Capital structure and cost of capital in public sector enterprises in Nepal. Ph. D. Thesis, Faculty of Management. University of Delhi, Delhi.

Bhattarai, Y.R. (2008).Determinants of capital structure: The Nepalese evidence, M.Phil.Thesis, Faculty of Management, Tribhuvan University, Kirtipur.

Chang, R. P. \& Rhee, S. G. (1990). The impact of personal taxes on corporate dividend policy and capital structure decision, Financial Management, 19(2).

Chaplinsky, S. \&Niehaus, G. (1990). The determinants of inside ownership and leverage. Working Paper. University, of Michigan.

De-Angelo, H \&Masulis, R. W (1980). Optimal capital structures under corporate and personal taxation. The Journal of Financial Economics.

Deo M. and Jackline .S. (2009). The Determinants of debt ownership structure - Some Empirical Evidence. Indian Journal of Finance.

Hunsaker, J. (1999). The Role of Debt and Bankruptcy Statutes in Facilitating Tacit Collusion. Managerial and Decision Economics, Vol. 20,

Jensen, M. \& Meckling, W. (1976). Theory of the firm: managerial behaviour, agency costs and ownership structure. Journal of Financial Economics.

Modigliani, F, \& Merton, H. M. (1958). Capital structure theory and practice. American Economic Review, 48(3).

Modigliani, F. \& Miller, M. H. (1963). Corporate tax shield and the cost of capital: a correction. American Economic Review, 53(3).

Paudel, R. B. (1994). Industrial finance in Nepal. Ph. D. Thesis, Faculty of Management, Tribhuvan University, Kirtipur.

Pokharel, P. R. (2011). Determinants of capital structure in Nepalese pharmaceuticals companies. Unpublished M. Phil. Thesis Faculty of Management, Tribhuvan University, Kirtipur.

Rajan, R. \& Zingales, L. (1995). What do we know about the capital structure? Some evidence from international data. Journal of Finance, 50: 1421-60.

Ross, S. (1977). The determinants of financial structure: the incentive signaling approach. BellJournal of Economics, 8, 23- 40.

Sharma, S. K. (1995). Determinants of corporate capital structure: An empirical analysis of selected manufacturing industries in India. Ph. D. Dissertation: University of Delhi.

Shrestha, M. K. (1985). Analysis of Capital Structure in Selected Public Enterprises. Prashasan: The Nepalese Journal of Public Administration 16.

Shrestha, R. D. (1993). Capital Structure of Selected and Listed Companies in Nepal. Pravaha Journal of Management 10.

Thies, C.F. \&Klock, M.S. (1992). Determinants of capital structure. Review of Financial Economics, 1.

Titman, S. \& Wessel. R. (1988). The determinants of capital structure choice. Journal of Finance, 43(1).

Wald, J.K. (1999). How firm characteristics affect capital structure: an international comparison? Journal of Financial Research, 22. 